\title{
Pola Kuman Pada Ruang Publik, Ruang Pelayanan, dan Ruang Perawatan Rumah Sakit Penyakit Infeksi Prof. Dr. Sulianti Saroso
}

\author{
Patterns of Germs in Public Space, Room Service, and \\ Treatment Room in Prof. Dr. Sulianti Saroso Hospital
}

\author{
Nurlaela \\ Rumah Sakit Penyakit Infeksi Prof. Dr. Sulianti Saroso
}

\begin{abstract}
Abstrak : Rumah sakit sebagai tempat perawatan dan penyembuhan pasien, ternyata rentan terjadinya infeksi penyakit, begitu pula yang terjadi di RSPI Prof. Dr. Sulianti Saroso. Oleh karena itu, perlu adanya penelitian jumlah dan jenis kuman di lingkungan RSPI-SS. Penelitian ini merupakan penelitian observasional dengan pendekatan cross selection. Jenis kuman yang akan diteliti adalah kuman yang terdapat pada lingkungan dan dapat berpindah melalui kontak tangan dan dapat menularkan penyakit pada manusia, yaitu jamur dan bakteri. Klasifikasi lingkungan dalam penelitian ini adalah area lingkungan publik, ruang pelayanan dan ruang penunjang medis RSPI-SS Jakarta dengan jenis sampel, yaitu kursi pengunjung, tombol lift, mesin absensi, tombol ATM, kran toilet, pegangan pintu, loket, keyboardkomputer, gagang telpon, dinding, meja nurse stasion, stetoskop, lantai, inhalasi, suction, tempat tidur, inspirasi ventilator, kaset ventilator, kursi dorong, troli tindakan, meja pasien, tanometer, gagang kloter, endoskopi, troli makanan, troli linen, dan meja dapur. Hasil penelitian ini antara lain dari 302 sampel yang terdiri dari specimen permukaan alat dan lingkungan rumah sakit ditemukan 129 sampel $(42,715 \%)$ yang positif terdapat kuman. Jamur merupakan jenis kuman yang paling banyak terdapat pada lingkungan RSPI Prof. Dr. Sulianti Saroso $(98.450 \%)$. Lantai adalah jenis sampel yang terbanyak ditemukannya kuman 23 sampel (17,8\%). Kemudian keyboard komputer 18 sampel $(14,0 \%)$ dan tempat tidur 17 $(13,2 \%)$.
\end{abstract}

Kata Kunci : kuman lingkungan, penyebaran kuman, lingkungan rumah sakit.

\begin{abstract}
Hospital as a patient care and healing, it turns susceptible to infectious diseases, as well as occurring in RSPI Prof. Dr Sulianti Saroso. Therefore, it is necessary to study the number and types of bacteria in the environment RSPI - SS. This study was an observational study with cross selection. Types of germs that will be examined are the germs found in the environment and can move through hand contact and can transmit the disease to humans, ie fungi and bacteria. Environmental classification in this research is the area of public environment, room service and medical support space in RSPI-SS with the type of sample, ie visitor chairs, elevator buttons, attendance machine, ATM buttons, toilet faucets, doorknobs, counters, computer keyboards , up the phone, walls, tables nurse station, stethoscope, flooring, inhalation, suction, bed, inspiration ventilators, ventilator tape, push chairs, trolleys action, the patient table, tanometer, handles fleet, endoscopy , food trolley, linens trolley, and tables kitchen. The results of this study are composed of 302 samples from the surface of the specimen and the hospital environment tool found 129 samples ( $42.715 \%$ ) were positive for bacteria. Mushroom is a type of bacteria that are most numerous in the environment RSPI Prof. Dr Sulianti Saroso ( $98450 \%$ ). The floor is the most sample types discovery of germs 23 samples (17.8\%). Then the computer keyboard 18 samples (14.0\%) and the bed 17 (13.2\%).
\end{abstract}

Keywords : environmental germs, spreading germs, the hospital environment

Korespondensi : Nurlaela

RSPI Sulianti Saroso, JI. Baru Sunter Permai

Raya Jakarta Utara 14340

Phone : 021-6506559Fax : 021-6401411

Email : elakhana@yahoo.com

\section{PENDAHULUAN}

Meningkatnya kasus infeksi nosokomial menjadi salah satu faktor dalam menilai mutu pelayanan rumah sakit. Penyakit infeksi karena kuman dapat terjadi di mana pun, tak terkecuali di tempat-tempat kesehatan seperti rumah sakit, puskesmas, dan klinik. Sebagian rumah sakit masih menjadi tempat menularkan berbagai macam jenis penyakit infeksi. Salah satu aspek yang mesti diperhatikan pihak rumah sakit adalah melengkapi rumah sakit dengan berbagai perangkat dan fasilitas pencegahan infeksi. Jika tidak bisa dikendalikan, infeksi nosokomial bisa menyebabkan pasien tak kunjung sembuh. Akibatnya, masa berobat menjadi lebih panjang dan biaya berobat semakin membengkak. Kondisi seperti itu jelas membebani psikologi pasien dan menimbulkan rasa pesimistis.

Penularan langsung bisa melalui udara dan benda-benda yang ada di rumah sakit, seperti tempat tidur, dinding, dan alat medis. Sementara itu penularan secara tidak langsung bisa melalui tenaga medis ke pasien, antarpasien, atau pasien terhadap pengunjung. Rumah sakit harus mampu menciptakan lingkungan bersih 
sehingga terwujud rumah sakit sehat, bukan sebagai penyebar kuman penyakit.

Pencegahan terjadinya infeksi nosokomial diperlukan suatu rencana yang terintegrasi, terprogram, dan terpantau. Upaya itu termasuk membatasi transmisi organisme dari atau antar pasien dengan cara mencuci tangan dan penggunaan sarung tangan, tindakan septik dan aseptik, sterilisasi dan disinfektan, mengontrol risiko penularan dari lingkungan.

Sesuai karakternya, kuman beradaptasi dengan lingkungan dan cepat menyebar. Kuman dapat bertahan di suatu permukaan hingga dua jam dan berkembang biak dua kali lipat setiap 20 menit sekali. Kuman akan mati bila terkena air bersuhu di atas 140 derajat. Tidak hanya di rumah sakit, lingkungan seperti sekolah, tempat bermain anakanak, dan rumah merupakan tempat berkembangbiaknya kuman. Mencuci tangan dengan sabun, selain menghilangkan kotoran yang menempel di tangan, dapat mencegah timbulnya berbagai penyakit yang disebabkan oleh kuman, seperti radang tenggorokan, masalah saluran pernapasan, disentri, diare, dan bau badan. Membiasakan diri mencuci tangan dengan sabun adalah kegiatan preventif yang paling murah dan efektif dan dapat mengurangi biaya pengobatan kesehatan.

RSPI Prof. Dr. Sulianti Saroso adalah rumah sakit rujukan penyakit infeksi tipe B-pendidikan dengan kapasitas 168 tempat tidur. Beberapa jenis infeksi nosokomial yang terjadi di RSPI Prof. Dr. Sulianti Saroso ialah Infeksi Saluran Kelamin (ISK), infeksi Luka Operasi (ILO), penuomonia, sepsis, dan dekubitus. Jika dibiarkan terus terjadi tanpa ada penanganan lebih lanjut, hal ini akan semakin menyebabkan kerugian. Bukan hanya dari segi pembiayaan yang meningkat karena pasien akan lebih lama menginap di rumah sakit, tetapi juga dapat menyebabkan kematian. Demikian juga dengan pengunjung rumah sakit yang dapat tertular penyakit infeksi lainnya.

Oleh karena itu, penulis tertarik untuk mengetahui jumlah dan jenis kuman tertentu yang terdapat pada lingkungan RSPI Prof. Dr. Sulianti Saroso.

\section{METODE PENELITIAN}

Metode penelitian yang digunakan adalah penelitian observasional dengan pendekatan cross sectional. Jumlah sampel seluruhnya ada 302 (tiga ratus dua) buah sampel dari populasi yang ada. Pengumpulan data didapat dengan hasil pemeriksaan sampel di laboratorium yang diambil dengan teknik purposive sampling. Penelitian ini dilakukan di area publik, ruang pelayanan, dan ruang penunjang medis RSPI Prof. Dr. Sulianti Saroso, Jakarta yang dilaksanakan pada bulan Juli, Agustus dan September 2013.Titik sampel yang akan diambil antara lain : kursi pengunjung, tombol lift, mesin absensi, tombol ATM, kran toilet, pegangan pintu, loket, keyboardkomputer, gagang telpon, dinding, meja nurse stasion, stetoskop, lantai, inhalasi, suction, tempat tidur, inspirasi ventilator, kaset ventilator, kursi dorong, troli tindakan, meja pasien, tanometer, gagang kloter, endoskopi, troli makanan, troli linen, dan meja dapur.

Pengumpulan data berdasarkan observasi lapangan dengan mengambil sampel usap permukaan titik sampel. Pengambilan sampel dilakukan dengan cara cotton swab steril dimasukkan dalam tabung media Carry and Blair $10 \mathrm{ml}$ kemudian diusap ke atas permukaan sampel yang diambil. Selanjutnya cotton swab dimasukkan kembali kedalam tabung media Carry and Blair dan dibawa langsung ke laboratorium penelitian. Pemeriksaan laboratorium tentang jumlah dan jenis kuman yang terdapat pada sampel dilakukan di laboratorium penelitian RSPI Prof. Dr. Sulianti Saroso. Pemeriksaan sampel untuk menemukan kuman dilakukan dengan menginkubasi dan teknik kultur kuman. Urutan pemeriksaan yaitu sampel yang sudah diusap kemudian di tanam di media BA dan MC kemudian di inkubasi selama 24 jam. Pertumbuhan koloni di media BA dan MC dilihat dan kemudian dibuat gram. Bila gram tersebut hasilnya adalah jamur maka pemeriksaan sampel berhenti sampai di sini. Bila gram tersebut pertumbuhannya adalah gram lain (gram selain jamur) maka dilakukan dengan pemeriksaan sampel lanjutan dengan 
menggunakan media KIA, SSS, MIO, LAO, OF, Simonsitrat, MRVP. Bila pemeriksaan hasil sampel di atas menunjukkan adanya pertumbuhan koloni, selanjutnya diidentifikasi kuman tersebut (e.coli, pseudomonas, dan lain-lain). Terakhir catat hasilnya pada formulir hasil pemeriksaan sampel.

Batasan operasional penelitian ini adalah jumlah dan jenis kuman yang terdapat pada hasil sampel. Jenis kuman yang akan diteliti terbatas pada kuman yang terdapat pada lingkungan dan dapat ditularkan melalui kontak tangan dan menyebabkan penyakit, yaitu : bakteri dan jamur.

Tabel 2. Distribusi jenis sampel positif kuman

\begin{tabular}{|c|c|c|c|c|c|c|c|}
\hline No & Titik sampel & Jumlah & $\%$ & No & Titik sampel & Jumlah & $\%$ \\
\hline 1 & Pegangan Pintu & 8 & $6.2 \%$ & 12 & Kran Toilet & 4 & $3.1 \%$ \\
\hline 2 & Dinding & 5 & $3.9 \%$ & 13 & Tombol Lift & 2 & $1.6 \%$ \\
\hline 3 & Meja Pasien & 4 & $3.1 \%$ & 14 & Mesin Absen & 1 & $0.8 \%$ \\
\hline 4 & Troli Linen Bersih & 1 & $0.8 \%$ & 15 & Lantai & 23 & $17.8 \%$ \\
\hline 5 & Troli Makanan & 1 & $0.8 \%$ & 16 & Loket & 4 & $3.1 \%$ \\
\hline 6 & Meja Dapur & 1 & $0.8 \%$ & 17 & Gagang Telpon & 12 & $9.3 \%$ \\
\hline 7 & Meja Security & 1 & $0.8 \%$ & 19 & Keyboard Komputer & 18 & $14.0 \%$ \\
\hline 8 & Kursi Pengunjung & 7 & $5.4 \%$ & 20 & Tempat tidur & 17 & $13.2 \%$ \\
\hline 9 & Meja Nurse Station & 3 & $2.3 \%$ & 21 & Troli Tindakan & 3 & $2.3 \%$ \\
\hline 10 & Kursi Dorong & 4 & $3.1 \%$ & 22 & Kursi Pasien & 1 & $0.8 \%$ \\
\hline 11 & Stetoskop & 7 & $5.4 \%$ & 23 & Kaset Ventilator & 1 & $0.8 \%$ \\
\hline \multicolumn{6}{|c|}{ Total } & 129 & $100 \%$ \\
\hline
\end{tabular}

Dari 129 Titik sampel, jenis sampel positif kuman terbanyak ditemukan di lantai yaitu 23 sampel (17,8\%). Kemudian keyboard komputer 18 sampel $(14,0 \%)$ dan tempat tidur 17 $(13,2 \%)$.

Tabel 3. Distribusi hasil pemeriksaan positif di ruang public

\begin{tabular}{|c|l|c|c|c|}
\hline No & \multicolumn{1}{|c|}{ Lokasi } & Titik Sampel & Jenis Kuman & Koloni \\
\hline 1 & Koridor Lantai 3 & Kursi pengunjung & Jamur & 1 \\
\hline 2 & Koridor Lantai 1 & Kursi pengunjung & Jamur & 1 \\
\hline 3 & Koridor Lantai 1 & Tombol lift & Jamur & 1 \\
\hline 4 & Koridor Lantai 1 & Mesin absensi & Jamur & 1 \\
\hline 5 & ATM Luar & Kran toilet & Jamur & 2 \\
\hline 6 & Toilet Umum Poli Anak & Kran toilet & Jamur & 2 \\
\hline 7 & Toilet Koridor Lantai 2 & Pegangan pintu & Jamur & 1 \\
\hline 8 & Toilet Koridor Lantai 2 & Kran toilet & Jamur & 1 \\
\hline 9 & Toilet Adhyatma It. 1 Pria & Kran toilet & Jamur & 1 \\
\hline 10 & Toilet gudang farmasi & Pegangan pintu & Spora & 1 \\
\hline 11 & Toilet gudang farmasi & Meja sekuriti & Jamur & 1 \\
\hline 12 & Gedung Adhyatma & Keyboard komputer It. 3 & Jamur & 1 \\
\hline 13 & Gedung Adhyatma &
\end{tabular}


Jumlah koloni kuman di ruang publik/umum (13 sampel positif) rata-rata 1 koloni kuman jamur.

Tabel 4. Distribusi hasil pemeriksaan positif di ruang perawatan

\begin{tabular}{|c|c|c|c|c|c|c|c|c|c|}
\hline No & Lokasi & Titik sampel & $\begin{array}{c}\text { Jenis } \\
\text { kuman }\end{array}$ & Koloni & No & Lokasi & Titik sampel & $\begin{array}{c}\text { Jenis } \\
\text { kuman }\end{array}$ & Koloni \\
\hline 1 & ICU & Gagang telpon & Jamur & 1 & 24 & Dahlia 1 & $\begin{array}{l}\text { Pegangan } \\
\text { pintu }\end{array}$ & Jamur & 2 \\
\hline 2 & ICU & $\begin{array}{c}\text { Kaset } \\
\text { ventilator }\end{array}$ & Jamur & 1 & 25 & Dahlia 1 & Dinding & Jamur & 2 \\
\hline 3 & IGD & Lantai & Jamur & 50 & 26 & Dahlia 1 & Stetoskop & Jamur & 4 \\
\hline 4 & IGD & Tempat tidur & Jamur & 9 & 27 & Dahlia 1 & Lantai & Jamur & 4 \\
\hline 5 & IGD & Tombol lift IGD & Jamur & 4 & 28 & Dahlia 1 & troli tindakan & Jamur & 1 \\
\hline 6 & Mawar 2 & Gagang telpon & Jamur & 10 & 29 & Dahlia 1 & Tempat tidur & Jamur & 6 \\
\hline 7 & Mawar 2 & $\begin{array}{l}\text { Pegangan } \\
\text { pintu }\end{array}$ & Jamur & 20 & 30 & Dahlia 1 & Kursi dorong & Jamur & 80 \\
\hline 8 & Mawar 2 & Dinding & Jamur & 5 & 31 & Dahlia 1 & Meja pasien & Jamur & 2 \\
\hline 9 & Mawar 2 & $\begin{array}{c}\text { Meja nurse } \\
\text { station }\end{array}$ & Jamur & 2 & 32 & Nusa Indah 4 & $\begin{array}{c}\text { Meja nurse } \\
\text { station }\end{array}$ & Jamur & 1 \\
\hline 10 & Mawar 2 & Lantai & Jamur & 4 & 33 & Nusa Indah 4 & Stetoskop & Jamur & 4 \\
\hline 11 & Mawar 2 & $\begin{array}{l}\text { Keyboard } \\
\text { komputer }\end{array}$ & Jamur & 2 & 34 & Nusa Indah 4 & Lantai & Jamur & 30 \\
\hline 12 & Mawar 2 & Troli tindakan & Jamur & 2 & 35 & Nusa Indah 4 & $\begin{array}{l}\text { Keyboard } \\
\text { komputer }\end{array}$ & Jamur & 3 \\
\hline 13 & Mawar 2 & Tempat tidur & Jamur & 32 & 36 & Nusa Indah 4 & Tempat tidur & Jamur & 1 \\
\hline 14 & Mawar 2 & Kursi dorong & Jamur & 20 & 37 & Nusa Indah 4 & Meja pasien & Jamur & 20 \\
\hline 15 & Mawar 1 & Lantai & Jamur & 1 & 38 & Nusa Indah 3 & Tempat tidur & Jamur & 1 \\
\hline 16 & Dahlia 2 & Dinding & Jamur & 27 & 39 & Nusa Indah 2 & $\begin{array}{c}\text { Meja nurse } \\
\text { station }\end{array}$ & $\begin{array}{c}\text { Spora } \\
\text { dan hyfa }\end{array}$ & 1 \\
\hline 17 & Dahlia 2 & Stetoskop & Jamur & 28 & 40 & Nusa Indah 2 & Lantai & Jamur & 1 \\
\hline 18 & Dahlia 2 & Lantai & Jamur & 8 & 41 & Nusa Indah 2 & $\begin{array}{l}\text { keyboard } \\
\text { komputer }\end{array}$ & Jamur & 1 \\
\hline 19 & Dahlia 2 & $\begin{array}{l}\text { Keyboard } \\
\text { komputer }\end{array}$ & Jamur & 30 & 42 & Nusa Indah 2 & Tempat tidur & Jamur & 1 \\
\hline 20 & Dahlia 2 & Troli tindakan & Jamur & 9 & 43 & Nusa Indah 2 & kursi dorong & Jamur & 1 \\
\hline 21 & Dahlia 2 & Tempat tidur & Jamur & 16 & 44 & Nusa Indah 2 & Meja pasien & Jamur & 1 \\
\hline 22 & Dahlia 2 & Kursi dorong & Jamur & 10 & 45 & Nusa Indah 1 & Lantai & Jamur & 1 \\
\hline 23 & Dahlia 1 & Gagang telpon & Jamur & 2 & 46 & Nusa Indah 1 & Meja pasien & Jamur & 1 \\
\hline
\end{tabular}

Jumlah koloni kuman terbanyak di ruang perawatan (46 sampel positif jamur) yaitu kursi dorong Ruang Dahlia I sebanyak 80 koloni, lantai IGD 50 koloni, tempat tidur Mawar II sebanyak 32 koloni, keyboard komputer Dahlia II 30 koloni, dan lantai Nusa Indah IV 30 koloni. 
Tabel 5. Distribusi hasil pemeriksaan positif di ruang pelayanan (Poli)

\begin{tabular}{|c|c|c|c|c|c|c|c|c|c|}
\hline No & Lokasi & $\begin{array}{c}\text { Titik } \\
\text { sampel }\end{array}$ & $\begin{array}{c}\text { Jenis } \\
\text { kuman }\end{array}$ & Koloni & No & Lokasi & $\begin{array}{c}\text { Titik } \\
\text { sampel }\end{array}$ & $\begin{array}{c}\text { Jenis } \\
\text { kuman }\end{array}$ & Koloni \\
\hline 1 & P. Gigi & Stetoskop & Jamur & 1 & 24 & P.Anak & stetoskop & Jamur & 1 \\
\hline 2 & P.Gigi & keyboard & Jamur & 1 & 25 & P.Anak & $\begin{array}{l}\text { tempat } \\
\text { tidur }\end{array}$ & Jamur & 1 \\
\hline 3 & P.Gigi & $\begin{array}{l}\text { gagang } \\
\text { telpon }\end{array}$ & Jamur & 1 & 26 & P.Anak & lantai & Jamur & 1 \\
\hline 4 & P.Syaraf & $\begin{array}{l}\text { tempat } \\
\text { tidur }\end{array}$ & Jamur & $>100$ & 27 & P.Dalam & keyboard & Jamur & 3 \\
\hline 5 & P.Syaraf & kursi & Jamur & $>100$ & 28 & P.Dalam & lantai & Jamur & 15 \\
\hline 6 & P.Syaraf & keyboard & Jamur & $>100$ & 29 & P.MCU & lantai & Jamur & 1 \\
\hline 7 & P.Syaraf & $\begin{array}{c}\text { pegangan } \\
\text { pintu }\end{array}$ & $\begin{array}{l}\text { Klebsiella } \\
\text { pneumoni }\end{array}$ & & 30 & P.Remed & $\begin{array}{c}\text { tempat } \\
\text { tidur }\end{array}$ & Jamur & 24 \\
\hline 8 & P.Syaraf & $\begin{array}{c}\text { gagang } \\
\text { telpon }\end{array}$ & Jamur & $>100$ & 31 & P.Remed & keyboard & Jamur & 8 \\
\hline 9 & P.Syaraf & lantai & E.coli & & 32 & P.Remed & $\begin{array}{c}\text { pegangan } \\
\text { pintu }\end{array}$ & Jamur & 8 \\
\hline 10 & P.Syaraf & dinding & Jamur & $>100$ & 33 & P.Remed & lantai & Jamur & 50 \\
\hline 11 & P.Karyawan & $\begin{array}{c}\text { tempat } \\
\text { tidur }\end{array}$ & Jamur & 10 & 34 & P. Kulit\&Kelamin & $\begin{array}{c}\text { tempat } \\
\text { tidur }\end{array}$ & Jamur & 43 \\
\hline 12 & P.Karyawan & keyboard & Jamur & $>100$ & 35 & P. Kulit\&Kelamin & keyboard & Jamur & 8 \\
\hline 13 & P.Karyawan & $\begin{array}{l}\text { gagang } \\
\text { telpon }\end{array}$ & Jamur & 37 & 36 & P.Kulit\&Kelamin & $\begin{array}{c}\text { pegangan } \\
\text { pintu }\end{array}$ & Jamur & 10 \\
\hline 14 & P.Karyawan & lantai & Jamur & $>100$ & 37 & P.Kulit\&Kelamin & lantai & Jamur & 1 \\
\hline 15 & P.Paru & stetoskop & Jamur & 45 & 38 & P.Orthopedi & stetoskop & Jamur & 4 \\
\hline 16 & P.Paru & $\begin{array}{l}\text { tempat } \\
\text { tidur }\end{array}$ & Jamur & 15 & 39 & P.Orthoped & $\begin{array}{c}\text { tempat } \\
\text { tidur }\end{array}$ & Jamur & 16 \\
\hline 17 & P.Paru & $\begin{array}{c}\text { gagang } \\
\text { telpon }\end{array}$ & Jamur & 5 & 40 & P.Orthoped & kursi & Jamur & 75 \\
\hline 18 & P.Paru & lantai & Jamur & 10 & 41 & P.Orthoped & keyboard r & Jamur & 9 \\
\hline 19 & P.Kebidanan & $\begin{array}{c}\text { tempat } \\
\text { tidur }\end{array}$ & Jamur & 30 & 42 & P.Orthoped & lantai & Jamur & 58 \\
\hline 20 & P.Kebidanan & kursi & Jamur & 2 & 43 & P.Orthoped & kursi & Jamur & 3 \\
\hline 21 & P.Kebidanan & keyboard & Jamur & 8 & 44 & P.THT & keyboard & Jamur & 4 \\
\hline 22 & P.Kebidanan & $\begin{array}{c}\text { gagang } \\
\text { telpon }\end{array}$ & Jamur & 2 & 45 & P.THT & lantai & Jamur & 18 \\
\hline 23 & P.Kebidanan & lantai & Jamur & 24 & & & & & \\
\hline
\end{tabular}

Jumlah koloni kuman terbanyak di ruang pelayanan (poli) (70 sampel positif) yaitu sebanyak 7 sampel terdapat jumlah kuman $>100$ koloni jamur yaitu pada Poli Saraf dan Poli Karyawan Selain itu ditemukan pula bakteri Klebsiella Pneumoni pada pegangan pintu Poli Saraf dan E. Coli pada lantai Poli Saraf. 
Tabel 6. Distribusi hasil pemeriksaan positif di ruang pelayanan (Lab, Dapur, Laundry kasir, apotik dan OK)

\begin{tabular}{|c|c|c|c|c|}
\hline No & Lokasi & Titik sampel & $\begin{array}{c}\text { Jenis } \\
\text { kuman }\end{array}$ & Koloni \\
\hline 1 & Lab & lantai & Jamur & 4 \\
\hline 2 & Lab & telpon & Jamur & 2 \\
\hline 3 & Lab & keyboard & Jamur & 6 \\
\hline 4 & Lab & kursi & Jamur & 12 \\
\hline 5 & Lab & loket & Jamur & 17 \\
\hline 6 & Radiologi & pegangan pintu & Jamur & 1 \\
\hline 7 & Radiologi & dinding & Jamur & 1 \\
\hline 8 & Radiologi & lantai & Jamur & 1 \\
\hline 9 & Radiologi & gagang telpon & Jamur & 1 \\
\hline 10 & Radiologi & keyboard & Jamur & 1 \\
\hline 11 & Radiologi & tempat tidur & Jamur & 1 \\
\hline 12 & Radiologi & kursi & Jamur & 1 \\
\hline 13 & Radiologi & loket & Jamur & 1 \\
\hline 14 & $\begin{array}{l}\text { Dapur } \\
\text { Gizi }\end{array}$ & lantai & Jamur & 1 \\
\hline 15 & $\begin{array}{l}\text { Dapur } \\
\text { Gizi }\end{array}$ & gagang telpon & Jamur & 1 \\
\hline 16 & $\begin{array}{l}\text { Dapur } \\
\text { Gizi }\end{array}$ & keyboard & Jamur & 1 \\
\hline 17 & $\begin{array}{l}\text { Dapur } \\
\text { Gizi }\end{array}$ & troli makanan & Jamur & 1 \\
\hline 18 & $\begin{array}{l}\text { Dapur } \\
\text { Gizi }\end{array}$ & meja dapur & Jamur & 1 \\
\hline 19 & Laundry & lantai & Jamur & 1 \\
\hline 20 & Laundry & $\begin{array}{l}\text { troli linen } \\
\text { bersih }\end{array}$ & Jamur & 1 \\
\hline 21 & Apotik & loket & Jamur & 1 \\
\hline 22 & Kasir & loket & Jamur & 1 \\
\hline 23 & OK & gagang telpon & Jamur & 1 \\
\hline 24 & OK & keyboard & Jamur & 1 \\
\hline 25 & OK & tempat tidur & Jamur & 1 \\
\hline
\end{tabular}

Jumlah koloni kuman terbanyak di ruang pelayanan (laboratorium, kasir, apotik,gizi dan OK) adalah di laboratorium yaitu pada loket sebanyak 17 koloni jamur.

\section{PEMBAHASAN}

Dari 302 (tiga ratus dua) sampel yang terdiri dari usap kursi pengunjung, tombol lift, mesin absensi, tombol ATM, kran toilet, pegangan pintu, loket, keyboard komputer, gagang telpon, dinding, meja nurse stasion, stetoskop, lantai, inhalasi, suction, tempat tidur, inspirasi ventilator, kaset ventilator, kursi dorong, troli tindakan, meja pasien, tanometer, gagang kloter, endoskopi, troli makanan, troli linen, dan meja dapur, diketahui 42,05\% sampel tercemar atau terkontaminasi yang terdiri dari jamur (127 sampel) dan bakteri E. coli (1 sampel) dan Klebsiela Pneunomonia (1 sampel).

Jamur adalah polutan udara dalam ruangan yang paling penting dan sedikit dimengerti kebanyakan orang. Jamur ada dimana-mana pada lingkungan manusia. Sporanya melimpah di udara, pada permukaan, di dalam debu dan dalam air. Jamur dapat menyebabkan penyakit pada manusia dan sangat penting sebagai sumber pathogen. Jamur dikonsumsi dalam makanan dan metabolismenya digunakan untuk obat-obatan, antibiotic misalnya.

Jamur bukan tanaman atau hewan. Sebagian kingdom jamur adalah organisme uniseluler. Hasil metabolisme yang bervariasi misalnya air, $\mathrm{CO}_{2}$, ethanol, asam organic, enzim, $\mathrm{VOC}_{\mathrm{S}}$, dan toksin nonvolatile, dikeluarkan jamur ke lingkungan. Air dan $\mathrm{CO}_{2}$ adalah produk normal respirasi aerobic ${ }^{1}$.

Spora jamur diproduksi secara aseksual dan seksual. Reproduksi secara aseksual yang membentuk sel tunggal. Spora seksual adalah hasil rekombinasi dari dua sel. Kebanyakn jamur yang menambah kepada pencemar udara dalam ruangan adalah yang berasal dari reproduksi aseksual, dengan adaptasi terhadap lingkungan yang berubah menjadi hifa yang menyatu. Tahap aseksual selalu dengan cepat menghasilkan spora yang menjadi koloni jamur. Pada tahap seksual terjadi ketika kondisinya menguntungkan, dan menghasilkan spora yang lebih tahan lama yang dapat menyebar ke jarak yang sangat jauh ${ }^{2}$.

Kebanyakan jamur menggunakan material organik kompleks yang berasal dari makhluk tidak hidup untuk makan, kebutuhan air dan oksigen dan memiliki suhu optimum di dalam tingkat kenyamanan manusia. Jamur membutuhkan cahaya untuk permulaan sporulasi. Faktor lingkungan yang mengontrol pertumbuhan jamur sangat interaktif. Sebagai contoh, suhu optimum 
untuk pertumbuhan jamur sekitar $22^{\circ} \mathrm{C}$ pada media kultur satu namun $18^{\circ} \mathrm{C}$ pada media kultur yang lain. Demikian juga pertumbuhan terjadi pada water activity yang rendah pada suhu $22^{\circ} \mathrm{C}$ tapi tidak pada $18^{0} \mathrm{C}^{1}$.

Sumber makanan untuk jamur ada dimana-mana. Kebanyakan jamur dapat menggunakan monosakrida dan disakarida sebagai sumber karbon. Contohnya jamur akan tumbuh pada buah yang sudah matang. Jenis jamur yang lain menggunakan selulosa, lignin, keratin, juga bebrapa jenis cat dan plastic sebagai sumber karbon. Studi laboratorium menjelaskan bahwa faktor biotik dan abiotik mempengaruhi pertumbuhan jamur dan reproduksinya. Faktor abiotik adalah air, suhu, kehadiran nutrient (karbon, nitrogen, sulfur, bermacam-macam makroelemen), $\mathrm{PH}$,cahaya,karbondioksida, dan tekanan oksigen. Faktor biotik mencakup interaksi antara organisme lain yang berhubungan dengan komunitas jamur, seperti antagonism, kompetisi, predasi dan parasitisme ${ }^{1}$.

Temperatur adalah faktor fisik yang cukup penting dan mempengaruhi pertumbuhan jamur. Setiap mikroorganisme memiliki kebutuhan temperature minimum dan optimum yang bertempat tidura-tempat tidura. Kebutuhan temperatur secara tidak langsung akan mempengaruhi kebutuhan minimum water activity.

Pada rentang water activity 0,2-0,8 terdapat perkiraan kenaikan sebesar 0,03 pada peningkatan temperature $10^{\circ} \mathrm{C}$. berdasarkan temperatur optimumnya, jamur dikelompokkan menjadi beberapa jenis yaitu mesofilik, psikrofilik dan termofilik ${ }^{1}$.

Suhu di dalam ruangan dalam rentang $18-24^{\circ} \mathrm{C}$ adalah suhu optimal bagi pertumbuhan kebanyakan jamur, meskipun beberapa jenis jamur dapat hidup juga di rentang suhu yang luas. Sedikit jamur yang mempunyai temperature optimum di atas $30^{\circ} \mathrm{C}$ yaitu Aspergillus fumigates. Jamur didalam lingkungan tidak tumbuh jika suhu di atas $30^{\circ} \mathrm{C}$. Spora jamur lebih tahan panas daripada miselia (mycelia) dan pada umumnya bertahan lebih lama suhu yang lebih luas rentangnya. ${ }^{1,3,4}$.
Pengaruh kesehatan yang disebabkan oleh jamur hanya sebagian kecil yang dpat menginfeksi manusia, tapi banyak yang dapat tumbuh pada bangunan dan mempunyai potensi untuk mengurangi kualitas udara dalam ruangan. Kebanyakan jamur yang menggunakan material yang tidak hidup dan sedikit yang dapat menyerang jaringan manusia. Beberapa factor yang mempengaruhi kemungkinan bahwa individu dapat mengalami efek kesehatan karena paparan jamur di dalam ruangan. Ini termasuk sifat dari jamur (misalnya alergi, iritasi/keracunan, atau infeksi), tingkat paparan (jumlah dan durasi), dan kerentanan masyarakat yang terkena dampak. Kerentanan bervariasi dengan kecenderungan genetik, usia, kondisi kesehatan, waktu pemaparan, dan sensitivitas ${ }^{2}$.

Efek kesehatan yang merugikan yang disebebkan jamur adalah reaksi elergi, efek beracun dan iritasi, serta infeksi. Kehadiran pertumbuhan jamur tidak selalu menunjukkan bahwa orang yang hadir di daerah ini akan menunjukkan efek kesehatan yang merugikan. Risiko paparan tertentu dapat signifikan dalm jangka panjang, khususnya individu dengan kondisi kesehatan yang mendasarinya seperti asma, sistem imun, atau alergi ${ }^{5}$.

Escherichia coli, atau biasa disingkat E. coli, adalah salah satu jenis spesies utama bakteri gram negatif. Pada umumnya, bakteri yang ditemukan oleh Theodor Escherich ini dapat ditemukan dalam usus besar manusia. Kebanyakan E.Coli tidak berbahaya, tetapi beberapa, seperti E.Coli tipe $0157: \mathrm{H} 7$, dapat mengakibatkan keracunan makanan yang serius pada manusia yaitu diare berdarah karena eksotoksin yang dihasilkan bernama verotoksin. Toksin ini bekerja dengan cara menghilangkan satu basa adenin dari unit $28 \mathrm{~S}$ rRNA, sehingga menghentikan sintesis protein. Sumber bakteri ini contohnya adalah daging yang belum masak, seperti daging hamburger yang belum matang ${ }^{6,7}$.

E. Coli yang tidak berbahaya dapat menguntungkan manusia dengan memproduksi vitamin $\mathrm{K} 2$, atau dengan 
mencegah bakteri lain di dalam usus. E. Coli banyak digunakan dalam teknologi rekayasa genetika. Biasa digunakan sebagai vektor untuk menyisipkan gen-gen tertentu yang diinginkan untuk dikembangkan. E. Coli dipilih karena pertumbuhannya sangat cepat dan mudah dalam penanganannya. Negara-negara di eropa sekarang sangat mewapadai penyebaran bakteri E.Coli ini, mereka bahkan melarang mengimpor sayuran dari luar ${ }^{6,7}$.

Klebsiella pneumonia pertama kali ditemukan oleh Carl Friedlander. Beliau adalah orang yang pertama kali mengidentifikasi bakteri Klebsiella pneumonia dari paru-paru orang yang meninggal karena pneumonia. Karena jasanya, Klebsiella pneumonia sering pula disebut bakteri Friedlander. Klebsiella pneumonia adalah bakteri Gram negatif yang berbentuk batang (basil). Klebsiella pneumonia tergolong bakteri yang tidak dapat melakukan pergerakan (non motil). Berdasarkan kebutuhannya akan oksigen, Klebsiella pneumonia merupakan bakteri fakultatif anaerob ${ }^{8}$.

Klebsiella pneumonia menyebabkan pneumonia dapat menginfeksi tempat lain di samping saluran pernafasan. Klebsiella merupakan suatu bakteri yang menimbulkan penyakit infeksi saluran pernapasan atas (hidung) yang kronis dan endemik di berbagai negara, termasuk Indonesia. Bakteri ini diberi nama berdasarkan penemunya, yaitu Edwin Klebs, seorang ahli mikrobiologi Jerman di abad ke-19. Bakteri genus Klebsiella termasuk ke dalam suku Klebsiellae, anggota famili Enterobacteriaceae. Klebsiella pneumonia ditemukan di dalam hidung, flora normal usus dan akan patogen bila menderita penyakit lain (penyakit paru-paru yang kronis) ${ }^{8}$.

Penyebaran terhadap pasien lain dapat terjadi melalui transmisi udara, tetapi biasanya terjadi melalui tangan pasien. Seorang karier nasal atau perineal pada dokter, perawat, atau pegawai rumah sakit lainnya dapat menjadi sumber munculnya penyakit, terutama jika kumannya ditularkan dalam jumlah yang besar ${ }^{8}$.

Klebsiella pneumonia banyak ditemukan di mulut, kulit, dan sal usus, namun habitat alami dari Klebsiella pneumonia adalah di tanah. Klebsiella pneumonia dapat menyebabkan pneumonia. Pneumonia adalah proses infeksi akut yang mengenai jaringan paruparu (alveoli). Pneumonia yang disebabkan oleh Klebsiella pneumonia dapat berupa pneumonia komuniti atau community acquired pneumonia, yaitu pneumonia yang di dapatkan dari masyarakat. Strain baru dari Klebsiella pneumonia dapat menyebabkan pneumonia nosomikal atau hospitality acquired pneumonia, yang berarti penyakit peumonia tersebut di dapatkan saat pasien berada di rumah sakit atau tempat pelayanan kesehatan ${ }^{8}$.

Klebsiella pneumonia umumnya menyerang orang dengan kekebalan tubuh lemah, seperti alkoholis, orang dengan penyakit diabetes dan orang dengan penyakit kronik paru-paru. Bakteri Klebsiella terdapat di mana-mana. Koloninya bisa ditemukan di kulit, kerongkongan, ataupun saluran pencernaan. Bahkan, bakteri ini juga bisa ada pada luka steril dan air kencing (urin). Sebenarnya, bakteri golongan ini mungkin saja ada sebagai flora alami "penghuni" usus besar dan kecil. Adapun pergerakan bakteri ini ke organ lain dikaitkan dengan lemahnya daya tahan penderita ${ }^{8}$.

Klebsiella pneumonia merupakan jenis bakteri golongan Klebsiella yang banyak menginfeksi manusia. la adalah kuman oportunis yang ditemukan pada lapisan mukosa mamalia, terutama paru-paru. Penyebarannya sangat cepat, terutama diantara orang-orang yang sedang terinfeksi bakteri-bakteri ini. Gejalanya berupa pendarahan dan penebalan lapisan mukosa organ. Bakteri ini juga merupakan salah satu bakteri yang menyebabkan penyakit bronchitis. Klebsiella pneumonia dapat menyebabkan penyakit karena mempunyai dua tipe antigen pada permukaan selnya ${ }^{8}$ :

1. Antigen $\mathrm{O}$

Antigen $\mathrm{O}$ adalah lipopolisakarida yang terdapat dalam sembilan varietas.

\section{Antigen $\mathrm{K}$}

Antigen $\mathrm{K}$ adalah polisakarida yang dikelilingi oleh kapsula dengan lebih dari 80 varietas. 
Kedua antigen ini meningkatkan patogenitas Klebsiella pneumonia. Selain itu, Klebsiella pneumonia mampu memproduksi enzim ESBL (Extended Spektrum Beta Lactamase) yang dapat melumpuhkan kerja berbagai jenis antibiotik. Hal ini dapat menyebabkan bakteri kebal dan menjadi sulit dilumpuhkan. Cara penularan (infeksi) dari Klebsiella pneumonia pada pasien rawat inap dapat melalui 3 cara, yaitu ${ }^{8}$ :

1. Aspirasi cairan gaster atau orofaring yang mengandung koloni kuman patogen.

2. Penyebaran kuman secara hematogen ke paru

3. Penyebaran melalui udara oleh aerosol atau droplet yang mengandung mikroba.

Pada umumnya, gejala-gejala penyakit yang ditimbulkan oleh bakteri golongan Klebsiellae adalah sama. Akan tetapi, setiap penyakit berdasarkan jenis spesies Klebsiella-nya masing-masing punya ciri khas. Klebsiella pneumonia yang menyebabkan penyakit paru-paru memberikan penampakan berupa pembengkakan paru-paru sehingga lobus kiri dan kanan paru-paru menjadi tidak sama; demam (panas-dingin); batuk-batuk (bronkhitis); penebalan dinding mukosa; dan dahak berdarah. Sedangkan, Klebsiella rhinoscleromatis dan Klebsiella ozaenae yang menyebabkan rinoschleroma dan ozaena memberikan gejala pembentukan granul (bintik-bintik), gangguan hidung, benjolanbenjolan di rongga pernapasan (terutama hidung), sakit kepala, serta ingus hijau dan berbau ${ }^{8}$.

Kondisi lingkungan yang mendukung dapat memacu pertumbuhan dan reproduksi bakteri. Faktor lingkungan yang berpengaruh terhadap pertumbuhan dan reproduksi bakteri adalah suhu, kelembapan dan cahaya. Kemungkinan sumber kuman juga berasal dari pasien, perawat dan pengunjung serta aktivitas pembersihan ruangan seperti menyapu. Hal ini memungkinkan kuman yang terdapat di lantai terhempas karena ukurannya yang sangat kecil. Sebagian kuman pathogen berasal dari pasien yang berada pada ruang perawatan. Sumber berikutnya dari hasil berbagai kegiatan rumah sakit, baik secara langsung maupun tidak langsung berhubungan dengan pelayanan medis menghasilkan produk samping berupa sampah dan limbah yang diindikasikan sebagai reservoir / tempat hidup kuman.

\section{KESIMPULAN}

Berdasarkan hasil penelitian yang telah dilakukan, dapat disimpulkan bahwa :

1. Dari 302 sampel yang terdiri dari specimen permukaan alat dan lingkungan rumah sakit ditemukan 129 sampel (42,715\%) yang positif terdapat kuman.

2. Jamur merupakan jenis kuman yang paling banyak terdapat pada lingkungan RSPI Prof. Dr. Sulianti Saroso $(98.450 \%)$.

3. Lantai adalah jenis sampel yang terbanyak ditemukannya kuman 23 sampel (17,8\%). Kemudian keyboard komputer 18 sampel $(14,0 \%)$ dan tempat tidur $17(13,2 \%)$.

4. Jumlah koloni kuman terbanyak di ruang perawatan (46 sampel positif jamur) yaitu kursi dorong Ruang Dahlia I sebanyak 80 koloni, lantai IGD 50 koloni, tempat tidur Mawar II sebanyak 32 koloni, keyboard komputer Dahlia II 30 koloni, dan lantai Nusa Indah IV 30 koloni.

5. Jumlah koloni kuman terbanyak di ruang pelayanan (70 sampel positif) yaitu sebanyak 7 sampel terdapat jumlah kuman $>100$ koloni jamur yaitu pada Poli Saraf (tempat tidur, kursi pengunjung, keyboard komputer, gagang telpon, dan dinding), Poli Karyawan (keyboard komputer dan lantai). Selain itu ditemukan pula bakteri Klebsiella Pneumoni pada pegangan pintu Poli Saraf dan E. Coli pada lantai Poli Saraf.

6. Jumlah koloni kuman di ruang publik / umum (13 sampel positif ) rata-rata 1 koloni kuman jamur. 


\section{SARAN}

Saran yang dapat dikemukakan ialah melakukan pembersihan dan desinfeksi sesuai dengan SOP yang berlaku untuk mengurangi jumlah kuman, terutama yang pathogen; membatasi jumlah pengunjung terutama, pada ruang pelayanan; penempatan handsrub untuk area pengunjung,memasyarakatkan pentingnya cuci tangan baik kepada petugas maupun pengunjung.

Pengendalian dari sumber kontaminasi jamur lebih disarankan daripada melakukan tindakan desinfeksi pada ruangan karena akan membuat mikroorganisme bakteri atau jamur menjadi lebih kebal terhadap desinfektan. Kebersihan individual baik pasien, penunggu pasien, pekerja medis dan non medis harus diperhatikan supaya tidak membawa mikroorganisme yang dapat lepas ke udara. Material dalam ruangan juga perlu diperhatikan untuk dibersihkan secara berkala dan dengan teknik yang benar.

\section{DAFTAR PUSTAKA}

1. Spengler, J., Samet, J.M., \& McCarthy, J. F. 2001. Indoor Air Quality. New York: McGraw-Hill.

2. Haisley, P., \& Wong, G. 2002. Fungal Colonization of Building Material and Impact on Occupant Health. Manoa : Departement of Botany, University of Hawai'i.

3. Gutarowska, B., \& Piotrowska, M. 2007. Methods of Mycological Analysis in Buildings. Buildings and Environment 42, 1843-1850.

4. Flannigan, B. 1997. Air Sampling For Fungi in Indoor Environments. Aerosol Science Vol 28, No.3, 381392.

5. Eduard, W. 2009. Fungal Spores : $A$ Critical Review of The Toxicological and Epidemiological Evidence As A Basisi For Occupational Exposure Limit Setting. Crit Rev Toxicol 39, 799-864.
6. Dwidjoseputro. 1990. Dasar-Dasar Mikrobiologi. Jakarta : Djambatan

7. Prawiro, H. 1989. Ekologi Lingkungan Pencemaran. Semarang : Penerbit Satyawacana

8. Jawetz, 1996, Mikrobiologi Kedokteran, Jakarta : EGC 